\title{
Digitising the RED social network: revisiting the technological gatekeeper
}

\author{
Eoin Whelan, ${ }^{*}$ Willie Golden ${ }^{\dagger} \&$ Brian Donnellan ${ }^{\ddagger}$ \\ ${ }^{*}$ Department of Management and Marketing, Kemmy Business School, University of \\ Limerick, Co. Limerick, Ireland, email: eoin.whelan@ul.ie, 'J.E Cairnes School of \\ Business \& Economics, National University of Ireland Galway, Co. Galway, Ireland, email: \\ willie.golden@nuigalway.ie, and ${ }^{\ddagger}$ Innovation Value Institute, National University of Ireland \\ Maynooth, Co. Kildare, Ireland, email: brian.donnellan@nuim.ie
}

\begin{abstract}
This paper examines how the digitisation of the social network, and the resulting interplay between its online and offline components, has impacted the role of the technological gatekeeper in research and development (R\&D) settings. Previous studies have firmly established the technological gatekeeper to be a key node in the innovation process - acquiring, translating and disseminating novel information throughout the R\&D social network. Drawing on social network analysis and interview evidence from a software $R \& D$ group, we find that the gatekeeper role has undergone a division of labour. Theoretically, we contribute to the body of knowledge by developing an updated technological gatekeeper conceptual framework. For practitioners, we identify the competencies exhibited by the small number of communication specialists who are largely responsible for diffusing novel information. We then advise practitioners how to maximise the contribution of these 'stars' to the information flow network.
\end{abstract}

Keywords: social networks, community of practice, Web technologies, technological gatekeeper, social network analysis, software development

\section{INTRODUCTION}

Social networks are usually used to explain the use of personal relationships or personal ties in order to obtain knowledge, information and resources (Birley, 1985; Cross \& Parker, 2004). As such, it has been argued that social networks are fundamental to shaping our lives (Barabasi, 2003; Watts, 2004; Christakis \& Fowler, 2009). The study of social networks enjoys a deep and rich tradition, particularly in the fields of sociology, biology and anthropology. Social networks have proven to be influential in explaining why individuals make certain voting (Lazarsfeld et al., 1948), movie-going (Katz \& Lazarsfeld, 1955) and musical taste choices (Salganik et al., 2006), how a person lands a new job (Granovetter, 1973) or wins a promotion (Burt, 1992), how innovations and trends catch fire and spread exponentially throughout a 
population (Coleman et al., 1966; Rogers, 1995) and even the recent bank run that led to the collapse of Northern Rock (Christakis \& Fowler, 2009). Notwithstanding the obvious societal significance of social networks, it has also recently been argued that in the knowledge economy, social networks matter far more than we may realise (Brown, 2007). It is estimated that knowledge-based industries account for $48 \%$ of the Ireland's gross domestic product (OECD, 2006). If information is the critical input to $48 \%$ of the work being conducted in an economy, then the channels that distribute that information among individuals, groups and populations are possibly the supply chains of knowledge-intensive industries (Kings et al., 2008). For this reason, knowledge management researchers and practitioners have been increasingly advocating social networks, in the form of communities of practice and networks of practice, as essential building blocks of the knowledge economy (Swan et al., 1999; Brown \& Duguid, 2000; Davenport \& Prusak, 2000; Wenger et al., 2002; Davenport, 2005; Schenkel \& Teigland, 2008; Newell et al., 2009; Parise, 2009).

Yet, in today's world, our understanding of what constitutes a social network has been dramatically altered. With the advances in internet technologies, a person can be a member of many social networks ranging from face-to-face interactions with close personal friends to Web-based collaborations with globally dispersed unknown and anonymous colleagues (Whelan et al., 2010). Indeed, recent ethnographic research by Su et al. (2007) has found that throughout the working day, knowledge workers constantly switch between multiple social networks, all of which are a complex mixture of formal and informal, face-to-face and computermediated, intra-organisational and extra-organisational and work-related and private interactions. While internet-enabled social networks have generated considerable interest in the information systems (IS) community, this research has tended to focus only on the online component of these communities. Digital interactions between individuals are almost always embedded in and influenced by social networks (Agarwal et al., 2008), yet our understanding of the interplay between internet technologies and social networks is still just beginning (Silva et al., 2008). Research is needed to inform organisations how business value can be generated from this interplay (Parameswaran \& Whinston, 2007; Agarwal et al., 2008). Our purpose in this paper is to address this research gap by examining how the online and the offline components of a social network combine to facilitate the diffusion of valuable information.

To fulfil our research purpose, we examine the software research and development (R\&D) division of a multinational telecommunications firm. Accordingly, we follow the approach of previous R\&D social network studies and conceptualise the connections that R\&D professionals utilise through various modes of communication to conduct their work, both inside and outside the firm, as the social network (Cross et al., 2002; Allen et al., 2007; Doak \& Assimakopoulos, 2007; Chen \& Wang, 2008). To aid in the gathering and analysis of the data, we turn to the field of innovation management and adopt the theoretical lens of the technological gatekeeper (Allen \& Cohen, 1969; Allen, 1971; 1977; Tushman \& Katz, 1980; Katz \& Tushman, 1981; Tushman \& Scanlan, 1981). The technological gatekeeper is an established social network theory that has proven to be influential in explaining how information of the latest technological advances diffuse throughout the R\&D social network. However, the theory was formulated over 30 years ago when interpersonal communication in social networks was 
almost exclusively conducted in face-to-face settings. We argue that the gatekeeper theory needs to be revisited in light of the recent advances in internet technologies that have enabled social networks by dramatically altering how knowledge workers source and share their information. We contrast how the role of the gatekeeper is performed in a contemporary digitised social network with that of original gatekeeper studies. As such, we present findings in support of the research question: how has the digitisation of the R\&D social network impacted the role of the technological gatekeeper? In the context of this study, digitisation refers to the shift of some interpersonal communication from face-to-face channels to digital media such as email and online forums. Our conceptualisation of digitisation is commensurate with the socio-technical branch of IS, which considers technology in light of its social environment and not just as a technical artefact (Binney, 2002; Coakes, 2002; Coakes et al., 2002).

We adopt a case study approach and draw from social network analysis (SNA) and interview evidence. Our findings make a number of important contributions. The gatekeeper theory is extended through the development of an updated conceptual framework. We also discuss the practical implications of our findings and advise practitioners on how to organise resources to enable valuable information to diffuse more readily throughout internet-enabled social networks.

The paper continues with a discussion of how internet technologies have impacted social networks. This is followed by sections in which we conceptualise our theoretical lens of the technological gatekeeper. We then describe the case study site and consider the data collection methods adopted. The findings are then presented, followed finally by a discussion of the implications of these findings for research and practice.

\section{INTERNET-ENABLED SOCIAL NETWORKS}

The study of social networks, and the theories that explain them, has become a hot topic of research in the IS field. Journals such as Journal of the Association for Information Systems and Information Systems Research have dedicated special issues to the topic. Likewise, conferences such as European Conference on Information Systems and Hawaii International Conference on System Sciences have introduced tracks on social networks. This recent interest from the IS community has largely been driven by the latest generation of internet technologies, which have been labelled Web 2.0. Online applications that facilitate mass collaboration and self-organisation, such as blogs, wiki and user tagging systems, embody Web 2.0 initiatives. Popular online services - Facebook, Linkedln, MySpace, Twitter - are also to the fore of Web 2.0. While these platforms have attracted millions of members who generally use these networks for keeping track of their friends, the recent disaster in Haiti has demonstrated a more significant benefit of Web 2.0. For the first time, the US Homeland Security Department (HSD) and the Red Cross have begun monitoring Twitter posts, blogs and online forums to learn instantly about conditions in Haiti and send out alerts to government agencies in the country. On the 21st of January, a Twitter post reading 'Let's save this life, someone is still buried alive under the rubble at Rue Centre, Building Napolin' was picked up by an HSD centre, and a rescue team was subsequently dispatched to that location (USA Today, 2010). 
The prevalence of internet-enabled social networks has spurred a number of research streams. In one stream, IS scholars have applied established social network theories such as social capital (Nahapiet \& Ghoshal, 1998) in order to understand online team performance (Lionel et al., 2008) and the motivations of individuals to contribute their knowledge to online communities (Wasko et al., 2004; Wasko \& Faraj, 2005; Roberts et al., 2006; Shah, 2006). In a second stream, IS scholars have utilised the strength of weak ties (Granovetter, 1973) and community of practice theories (Brown \& Duguid, 2000; Wenger et al., 2002) to examine online coordination mechanisms (Kudaravailli \& Faraj, 2008; Silva et al., 2008; Ganley \& Lampe, 2009). A third stream of IS social network research has used theories of information diffusion (Burt, 1992; Rogers, 1995) to explain online influence (Hinz \& Spann, 2008), viral marketing (Bampo et al., 2008) and productivity effects in email networks (Aral et al., 2007). While these studies have generated many important insights, they have tended to concentrate only on the online component of digital social networks. Scant attention has been directed towards understanding how the online and offline components combine to facilitate information diffusion. One recent exception to the rule is the Kane \& Alavi (2008) study, which finds that when an information technology system is used by health-care employees with many social ties, this information flows throughout the health-care social network, resulting in improvements to the efficiency and effectiveness of client treatment.

With recent surveys showing that knowledge workers are increasingly demanding and using Web 2.0 technologies (McKinsey Consulting, 2007; CIO.com, 2008), business leaders would naturally be interested in understanding how the increasing digitisation of social networks impacts the diffusion of valuable information and what initiatives can be adopted to ensure this information reaches the right people at the right time. In this effort, we revisit the highly influential technological gatekeeper theory. Through decades of innovation research, the role of the gatekeeper has proven to be a critical factor in understanding the performance of R\&D organisations as gatekeepers have served as key nodes in the innovation process - acquiring, translating and disseminating novel information throughout the firm.

\section{THE TECHNOLOGICAL GATEKEEPER}

R\&D groups are charged with driving innovation in high-technology firms. In order for R\&D to sustain itself, the innovation literature emphasises the importance of acquiring diverse and novel information from beyond the organisation's boundaries (Allen, 1977; Tushman, 1977; Aldrich \& Herker, 1997; Newell \& Swan, 2000; Chesbrough, 2003; Nooteboom, 2004). This externally acquired information serves as the seeds for future technological developments (March \& Simon, 1958; Leonard-Barton, 1992) and helps to build the firm's future 'absorptive capacity' (Cohen \& Levinthal, 1990). A rich stream of research through the 1970 s and early 1980 s examined the processes through which scientific and technological information enters the R\&D social network. This particular stream was headed by Massachusetts Institute of Technology's (MIT) Thomas Allen, and his seminal book, Managing the Flow of Technology (Allen, 1977), documents over a decade's worth of studies with some of the largest American 
R\&D corporations. An analysis of the communication patterns in multiple R\&D networks revealed the existence of a small number of key people who mediated between the average R\&D professional and the world outside. These individuals were first termed 'technological gatekeepers' (Allen \& Cohen, 1969; Allen, 1971; 1977; Tushman, 1977; Allen et al., 1979; Katz \& Tushman, 1981; Tushman \& Scanlan, 1981) as they act as the 'gate' through which information of external technology flows into the R\&D network. A more formal definition explains that technological gatekeepers are those key individual technologists who are strongly connected to both internal colleagues and external sources of information and who possess the ability to translate between the two systems (Allen \& Cohen, 1969; Allen, 1977; Tushman \& Scanlan, 1981).

Subsequent studies have shown that the presence of gatekeepers is positively related to higher performance for product development projects (Tushman \& Katz, 1980; Katz \& Tushman, 1981) and an additional analysis reports that R\&D professionals reporting to gatekeeping supervisors were more likely to be promoted to managerial positions and at a younger age (Katz \& Tushman, 1983). Essentially, gatekeepers perform three tasks that make them critical to information flows in the R\&D social network. Firstly, they perform the task of external information acquisition. Gatekeepers act as the firm's antennae, scanning the outside world for emerging scientific and technological developments relevant to the work of their R\&D group. Secondly, they perform the task of external information translation. Gatekeepers have the ability to understand external information and deliver it in a way that ensures its use by others (Macdonald \& Williams, 1993). Thirdly, gatekeepers perform the task of internal information dissemination. Although gatekeepers may well have their own use for the information they acquire, they are also keenly interested in passing it on to others in the organisation for their use (Macdonald \& Williams, 1994). Much of their expertise lies in knowing who is doing what, both inside and outside the firm. However, gatekeepers do not simply release technological information on mass. Rather, they disseminate to targeted work colleagues whom they know would be able to use the information they have acquired.

While the technological gatekeeper has proved to be a highly influential theory of information diffusion in R\&D settings, the concept has received modest attention in recent times. The community of practice literature has highlighted the related concepts of central connectors, boundary spanners and knowledge brokers (Brown \& Duguid, 2000; Cross \& Prusak, 2002; Cross \& Parker, 2004); however, little discussion exists as to how these concepts build upon the gatekeeper theory or how they can be applied to digital social networks. The gatekeeper theory was formulated in the 1970s, a time when it was a difficult and time-consuming process for the average R\&D professional to acquire information from beyond the company's boundaries. Thus, the gatekeeper mediated with the outside world on their behalf. Due to the emergence of internet technologies, we now inhabit a world where the ability to access external information through connections to both people and documents is a vastly easier process (Davenport \& Prusak, 2000; Parise, 2009). As a result, some scholars have suggested that with online forums now facilitating the exchange of technical information across organisational boundaries, the role of the technological gatekeeper in R\&D social networks may be 
mitigated (Teigland \& Wasko, 2003; Assimakopoulos \& Yan, 2006). Indeed, an earlier pilot study conducted by ourselves (Whelan et al., 2010) provided preliminary evidence that the traditional gatekeeper did not exist to any great extent. Instead, the gatekeeper role was being performed by a combination of internet-enabled internal and external communication specialists. We now build on these initial findings and undertake an in-depth case study in order to address the question: how has the digitisation of the R\&D social network impacted the role of the technological gatekeeper?

\section{RESEARCH METHODOLOGY}

For the purpose of our research, a case study method is appropriate as the objective of the study is theory building (Eisenhardt \& Graebner, 2007), there is a need to focus on contemporary events (Benbasat et al., 1987; Yin, 1994) and the phenomenon of interest can not be studied outside its natural setting (Yin, 1994). The case study setting is further described later.

\section{Case study setting}

In an effort to stay consistent with the original gatekeeper studies, we also have collected data from a high-technology firm, TelCom, a telecommunications multinational that has requested to remain anonymous. TelCom was selected for study as it met the screening criteria established by the researchers (i.e. high-tech industry, >100 R\&D group members, focused on product development and operates globally). Additionally, management at TelCom was very receptive to the study and had agreed to provide a high level of access to the research team. The company has a turnover of $\$ 10.95$ billion and employs approximately 32000 people worldwide, of which 800 are based across two locations in Ireland. TelCom produces computer network equipment and software both for general businesses and specialised communication carriers. TelCom's Irish R\&D unit (referred to in the rest of the paper as Group A) employs 114 professionals, the majority of whom are software engineers. While the R\&D group is based in Ireland, its operations are on a global level. The majority of Group A's external stakeholders are located in North America, continental Europe and Australia. All 114 members of Group A are co-located in two open plan areas, which are roughly 10 metres apart. The group's primary area of expertise is in developing software for multimedia customer contact centres. TelCom markets this technology as a cost-effective way of ensuring that customer enquiries to businesses are answered as quickly and efficiently as possible. The solutions developed by Group A enable customers to interact with the contact centre via phone, internet, email, video and text messaging. The ability to keep abreast of the latest communication technologies and to integrate those into its offerings is of vital competitive importance to Group A. As an example, as data collection was taking place, Group A was beginning to experiment with the virtual world Second Life with the objective of integrating three-dimensional capabilities into its multimedia contact centre suite. 


\section{Data collection and analysis}

Data were gathered from Group A during the period October-December 2008. To increase validity of our findings, we incorporated multiple methods to triangulate the data. These data collection methods are summarised in Table 1.

Phase 1 involved analysing the flows of information into and around Group A using SNA techniques. SNA or sociometry is an established social science approach of studying human relations and social structures by disclosing the affinities, attractions and repulsions between people and objects (Moreno, 1937). SNA views social relationships as nodes and ties that can be illustrated visually and mathematically. As such, it can provide an X-ray of the inner workings of a particular network. With this tool, important patterns become visible, relationships between people can be better understood, the health of a group can be assessed and the people playing key roles within the group can be identified (Cross \& Parker, 2004).

The purpose of the SNA was to map the R\&D social network and to reveal the communication 'stars'. To collect these data, all R\&D members were asked to complete a short online questionnaire on their internal and external communications (see Appendix 1). The questions posed are closely aligned with those of the original gatekeeper studies. As such, our view of the world is consistent with the network analyst perspective that characterises the world in terms of durable relational structures where a connection between two individuals is rendered more or less probable by the encompassing of ties (Wasserman \& Faust, 1994; Gibson, 2005). We used the SNA software package UCINET v. 6.0 (Borgatti et al., 2002) to illustrate the information network in Group A. To increase validity, only reciprocated interactions between group members were included in the analysis. This ensured that group members who reported higher than actual interactions did not distort the analysis.

Following the approach of previous gatekeeper scholars (Allen, 1977; Tushman \& Katz, 1980; Katz \& Tushman, 1981), we categorised Group A members based on the SNA results from phase 1 as gatekeeper, internal communication star, an external communication star or non-star. Gatekeepers were those individuals who were in the top $20 \%$ of both the internal and external communication distributions. Internal stars were operationalised as those individuals in the top $20 \%$ of the internal communication distribution but below the top $20 \%$ of the external communication distribution. The same logic applies for external stars. Non-stars were those who fell below the top $20 \%$ in either internal or external communication. With this analysis, we found four gatekeepers, 12 external stars, 12 internal stars and 62 non-stars.

In phase 2, we conducted semi-structured interviews with 10 members of Group A. Details of the interviewees are provided in Table 2. To select the interviewees, the SNA evidence was

Table 1. The data collection methods

\begin{tabular}{ll}
\hline Methods & Group A \\
\hline Phase 1 - social network analysis & $\begin{array}{c}\text { Online survey issued to all } 114 \text { group members, } 90 \text { returned } \\
\text { completed }(79 \% \text { response rate })\end{array}$ \\
Phase 2 - semi-structured interviews & $\begin{array}{c}\text { Ten recorded and transcribed composed of two gatekeepers, three } \\
\text { externals stars, three internal stars and two non-stars }\end{array}$ \\
\hline
\end{tabular}


Table 2. Interviewee details

\begin{tabular}{lll}
\hline Node & Classification & Formal position \\
\hline 3 & Gatekeeper & Project leader \\
82 & Gatekeeper & Senior engineer \\
34 & External communication star & Project leader \\
68 & External communication star & Engineer \\
75 (Keith) & External communication star & Engineer \\
69 (Dorothy) & Internal communication star & Engineer \\
81 & Internal communication star & Senior engineer \\
28 & Non-communication star & Senior engineer \\
9 (Catherine) & Non-communication star & Engineer \\
\hline
\end{tabular}

used to identify key information flow relationships, and the key actors contributing to those relationships were specifically targeted for follow-up interviews. The objective of these interviews was to explore how the use of internet technologies impacts the acquisition, translation and dissemination functions of the technological gatekeeper in the R\&D social network. All interviews were conducted face-to-face with the average length being 55 minutes. In addition, all interviewees gave permission for the interview to be recorded. The procedures outlined in the dramaturgical model (Myers \& Newman, 2007) were adopted in order to ensure that high-quality interviews were conducted. Interview data analysis was performed using the NVivo (QSR International Pty Ltd, Doncaster, Victoria, Australia) software package and followed established inductive qualitative methods: coding, data categorisation and pattern identification (Miles \& Huberman, 1984; Yin, 1994; Eisenhardt \& Graebner, 2007).

\section{FINDINGS}

\section{SNA}

Software packages such as the one used in this investigation automatically transform raw network statistical data to generate sociograms. The software will group relationship clusters and will equalise the length of the ties where possible. Figure 1 provides the sociogram of the Group A social network. The nodes in the diagram are the individual members of Group A and the lines represent the flow of technical information between them. The gatekeepers are represented by diamonds, the internal stars by down triangles, the external stars by up triangles and the non-stars by circles. Ninety of the 114 members of Group A completed the SNA questionnaire, giving a response rate of $79 \%$. Nodes $92-114$ are isolated as they did not complete the questionnaire. The remaining isolated nodes had no reciprocated interactions with another member of the group.

The SNA data in Figure 1 reveal that only four members (nodes 3, 18, 20 and 82), or 4.5\%, of the group can be classified as technological gatekeepers. In the initial formulation of the concept, Allen reported the gatekeeper level to be almost $20 \%$, i.e. those classified as 


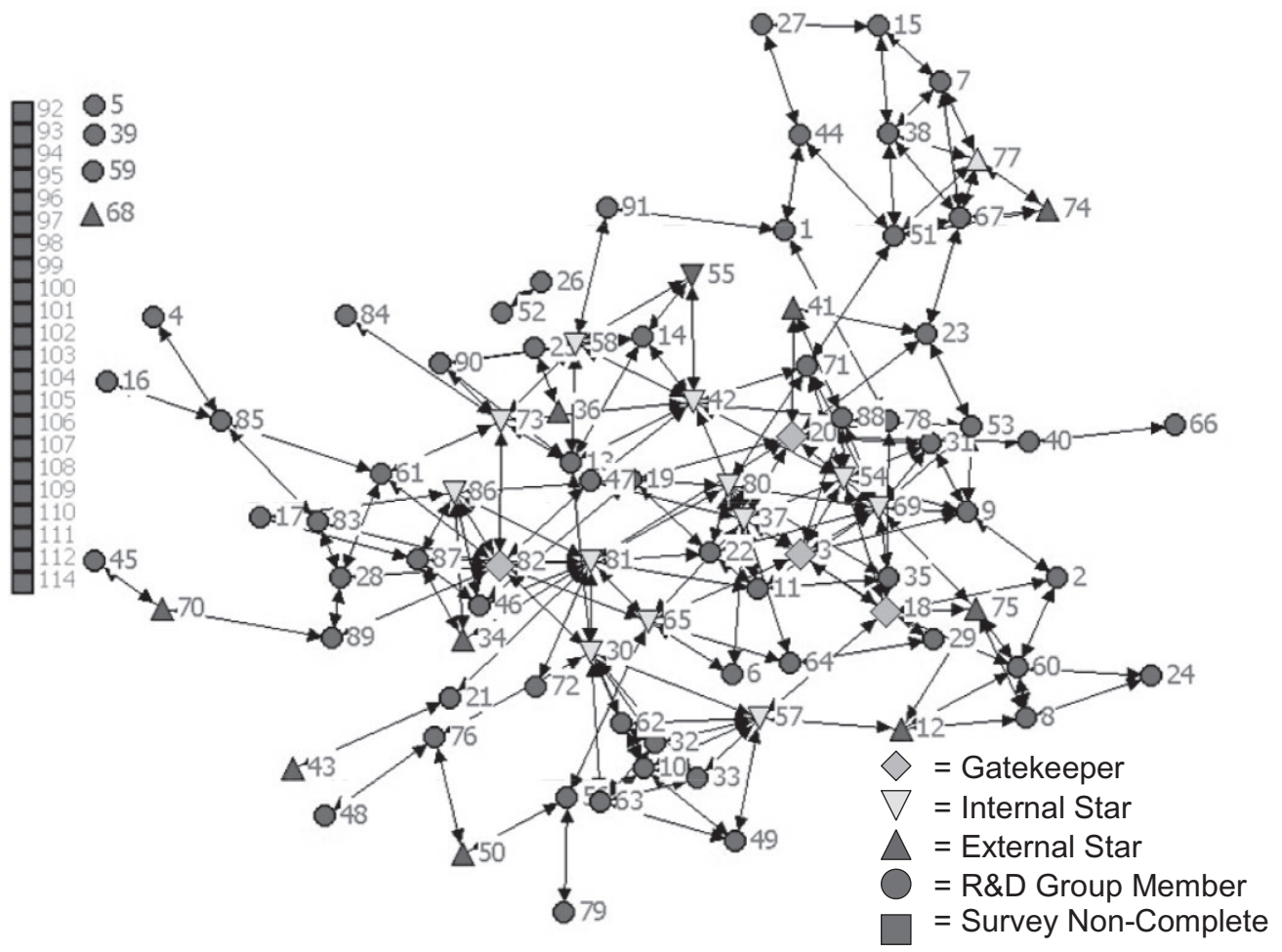

Figure 1. The R\&D social network.

internal stars were almost always external stars also (Allen \& Cohen, 1969; Allen, 1977). Our SNA data suggest that the gatekeeper role has undergone a division of labour. Those members of the group who are well connected outside the firm, the external stars, tend to have below average internal communications, hence the reason they tend to be located on the periphery of the sociogram in Figure 1. The average number of reciprocated internal interactions per group member is 4.198. Eleven of the 12 external stars fall below this level of internal communication. This suggests that the external stars tend to specialise in external communications to the detriment of internal communications. Similarly, nine of the 12 internal communication stars report below the group average for external communications, again indicating that internal stars tend to specialise in internal communications. While the SNA evidence on its own is not enough to prove that the gatekeeper role has undergone a division of labour, it does allow us to develop a proposition that can be further tested. To test our proposition that external and internal communication stars combine to perform the gatekeeper role, we isolated and analysed a number of key information flow relationships. These relationships are visually evident from the sociogram in Figure 1 and involve both external and internal communication stars i.e. nodes 74 and 77, 12 and 57, 75 and 69, 34 and 86, 34 


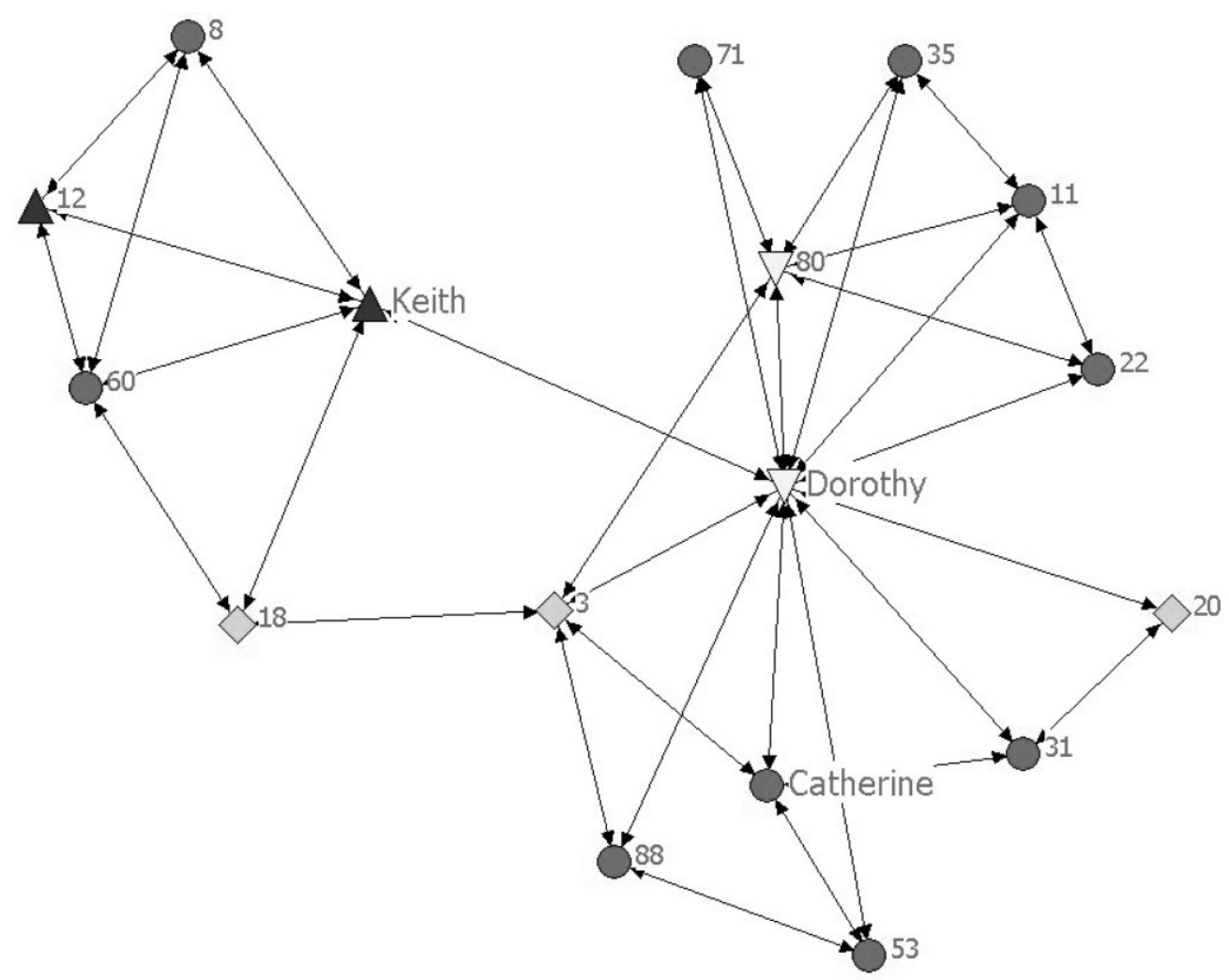

Figure 2. A sub-component of the R\&D social network.

and 81 and 36 and 42. To present and discuss each of these relationships would exceed the space available, thus we have chosen to focus on just one relationship as it provides a good representation of our overall findings.

Figure 2 is a sub-component of the R\&D social network that isolates the immediate connections of Keith ${ }^{1}$ (node 75) and Dorothy (node 69). Keith is the external star with the highest exposure to external sources of information of the whole group. While the sociogram reveals that Keith has a few internal connections of his own, outside information acquired would be more effectively disseminated around the group by Dorothy due to her extensive internal network. One of Dorothy's connections is Catherine (node 9), a rank-and-file R\&D professional. Interviews were conducted with these three individuals to explore the nature of the information flow relationship between them and the role and impact of internet technologies in enabling these connections. The analyses of these interviews are presented in the following section.

${ }^{1}$ All names mentioned are fictitious. 


\section{Analysis of interview data}

While the SNA evidence finds that technological gatekeepers do exist in Group A, they are few and far between. We interpreted the SNA evidence from Group A to purport that the gatekeeping role is more likely to be performed by a combination of external and internal communication stars. Focusing on the key actors identified in Figure 2 earlier, we now use the three constructs of the gatekeeper theory - external information acquisition, external information translation and internal information dissemination - to examine their role in the internetenabled social network. The key findings emanating from all 10 of our interviews are summarised in Table 3.

\section{External information acquisition}

In terms of technological advances, the telecommunications industry is one of the most rapidly evolving business fields. New software trends and technologies are constantly emerging and it is critical to the success, and indeed, the survival of TelCom, that the firm integrate these advances into their product offerings. In the words of one interviewee, 'We need to be constantly picking out and bringing in the new technologies. Something that was new 6 months

Table 3. Summary table of those performing the gatekeeping role

\begin{tabular}{|c|c|c|c|}
\hline & Key skills & Motivation/attitudes & Preferred media \\
\hline $\begin{array}{l}\text { External } \\
\text { Communication } \\
\text { Stars }\end{array}$ & $\begin{array}{l}\text { Ability to acquire relevant } \\
\text { information of external } \\
\text { technological developments; } \\
\text { narrow and deep knowledge } \\
\text { base, usually a PhD holder; } \\
\text { strong analytical skills }\end{array}$ & $\begin{array}{l}\text { Genuine interest in keeping } \\
\text { abreast of emerging trends in } \\
\text { their specialty; primarily acquire } \\
\text { information for own use but } \\
\text { lack the skills to disseminate } \\
\text { effectively }\end{array}$ & $\begin{array}{l}\text { Predominately } \\
\text { Web-based, e.g. } \\
\text { online communities, } \\
\text { wiki, blog, RSS } \\
\text { feeds, Google }\end{array}$ \\
\hline $\begin{array}{l}\text { Internal } \\
\text { Communication } \\
\text { Stars }\end{array}$ & $\begin{array}{l}\text { Ability to translate external } \\
\text { information into a form } \\
\text { understandable and relevant } \\
\text { to internal colleagues; wider } \\
\text { knowledge base, which } \\
\text { facilitates understanding the } \\
\text { context of new information } \\
\text { and how it fits with extant } \\
\text { knowledge }\end{array}$ & $\begin{array}{l}\text { Enjoy helping others; develop } \\
\text { their own knowledge from } \\
\text { these interactions; expect } \\
\text { reciprocation }\end{array}$ & $\begin{array}{l}\text { Email and face-to-face } \\
\text { interactions }\end{array}$ \\
\hline Gatekeepers & $\begin{array}{l}\text { Display both depth of knowledge } \\
\text { of external communication star } \\
\text { and breadth of knowledge of } \\
\text { internal communication star; } \\
\text { highly sociable with very good } \\
\text { networking skills enabling them } \\
\text { to develop extensive internal } \\
\text { and external networks }\end{array}$ & $\begin{array}{l}\text { May acquire information for their } \\
\text { own use but also transmit it to } \\
\text { others; enjoy helping others }\end{array}$ & $\begin{array}{l}\text { External - both } \\
\text { Web-based and } \\
\text { face-to-face } \\
\text { interactions; internal } \\
\text { - email and } \\
\text { face-to-face } \\
\text { interactions }\end{array}$ \\
\hline
\end{tabular}


ago, could be obsolete today'. The software industry necessitates that each of Group A's software engineers maintains a degree of awareness of emerging trends, yet the interview analysis reveals that it is the external communication stars and the small few gatekeepers who predominately act as the group's antennae, scanning the outside world for emerging technological developments relevant to the work of Group A.

The sociogram in Figure 2 showed that Keith, an external star, and Dorothy, an internal star, were strongly connected to each other. Keith explained that he had a very good grasp of the current developments in his field of voice recognition. He further explained that this knowledge is partly due to his own personal interest in the field and partly due to his formal role - he is expected to be a technology leader. His portal through which this information is sourced is through the internet. He is a member of a number of online forums and newsgroups that provide him with emails and Really Simple Syndication (RSS) feeds on the latest industry alerts. He scans these news feeds every day and even outside of work hours in order to identify emerging technologies relevant to Group A. When asked why he specialises in external communications to the detriment of internal communications, Keith explains that the identification and acquisition of useful information from beyond the firm's boundary has become a time-consuming and complex process, primarily due to the vast array of information now easily accessible through internet technologies. As much of the external information is acquired from the internet, the verification of that information to be accurate and reliable is an important step in the gatekeeping process. The source of external information needs to be verified, but additionally, software and telecommunications vendors are notorious for hyping their products and are particularly adapt at using the internet to generate this hype. As Keith explains, there are some very good blogs and some not so good, and he has spent considerable time '... identifying the good blogs... the ones written by solid engineers, technologists and researchers . . . as opposed to blogs from vendors. They are just marketing blogs for products which are not that really that useful'. As a result, Keith concentrates on filtering and verifying the relevant from the non-relevant technological information and relies on others, such as Dorothy, to diffuse the useful information he acquires throughout the R\&D social network.

\section{External information translation}

Keith and Dorothy frequently discuss if and how the external information identified by Keith can be integrated into the customer contact centre suite of products. If an emerging technology has potential, Dorothy uses her extensive knowledge of the internal social network to inform other R\&D colleagues who possess the expertise to potentially exploit that information. She usually uses email to inform these targeted individuals of the new development. However, external information of this type will not be considered by the recipients unless it is firstly translated into terms relevant to them. The reason for this is the heavy use of email in Group A. Many interviewees stated that they were overloaded with information as they could receive over 100 emails per day. As a result, most of the emails distributed around the group are rarely read fully. The interviewees explained that they have their email client set to preview mode whereby only the subject line and the first three to four lines of the email are displayed. If the receiver 
is not satisfied that the email is directly relevant to them, then the email will usually be deleted. As a result, the internal stars such as Dorothy carefully construct their emails so that information relating to new developments from outside the company gains the attention of the targeted recipients. An example of this translation process is provided in the following quote from Dorothy. She is quite aware that her emails are competing for recipient's attentions. She realises that most recipients will only scan the email and that the key to grabbing their attention is the email title and the first three to four sentences. In addition, she targets specific people as opposed to sending out 'blanket' emails:

From time to time I would get a good news alert from my colleagues about an emerging technology that we should be interested in. If I can't make use of that information myself, then I will try to direct it to someone who is in a good position to consider it. But we have a problem here... too much email. Most people would read e-mails through the preview mode. So I would always try to make sure the email has a snappy title. If they have their email set to preview mode, people might read the first 3-4 lines . . . but mostly it's the title they look at and you need to make sure that has all the information you want to get across. Another thing I do, I make sure l'd reference the person by their first name. If they think it's a blanket email, they'll usually just bin it.

\section{Internal information dissemination}

The interview with Dorothy revealed that she primarily uses email to alert her colleagues to emerging technologies. Much of the information she receives relating to new technologies is text-based and in is digital format (e.g. Web hyperlinks, Portable Document Format (PDF) documents, PowerPoint slides). As she explains in the following quote, email is seen as a more efficient system than face-to-face discussions for alerting colleagues to information in this format but that face-to-face discussions are usually needed afterwards:

You could walk down the corridor to someone's desk, sit with them for 30 minutes explaining a new application you've found ... for them to then turn around and say that they are not interested. I think it's better to email them first, let them make up their own mind whether they are interested in that information or not. Then if they are interested, they might come back to you for a chat. You are not wasting your time then. I think people here use email as a to-do list. It allows the person you are trying to contact to prioritise based on their own needs, rather than be interrupted by a phone call or someone sitting down for a chat.

Dorothy acknowledged that external information of this type usually comes to her from other colleagues in Group A who have more of an orientation to external sources of information. Dorothy provides an example of this chain. The sociogram in Figure 2 showed that Dorothy is the hub of that particular sub-component of the R\&D social network. She is connected to Keith and Catherine. Keith is an external communication star, who primarily uses online forums and newsgroups to acquire information of emerging technologies relevant to Group A. Catherine is a non-star who is kept abreast of these emerging trends through Dorothy. In the following 
quote, Dorothy recalls a recent instance where Keith discovered a new software application on the internet, which she later redirected to Catherine:

There was a particular version of a piece of software that came out in the last few months. It was pretty cool, and it was free for anyone to use. [Keith] got his hands on it first and sent it on to me. I had a good look at it too. It worked really well and I thought it might have potential for us. I sent that [software] out to [Catherine] to see if she could look at it further ... she knows more about those applications than I do. It worked out really well from what I recall.

This example of the open source software application was also discussed with Catherine, the non-star. She explains that she often receives emails from Dorothy alerting her to new developments that are potentially relevant for her. As she details in the following quote, sometimes she can use that information without having to revert back to the sender of the email, but on most occasions, a follow-up face-to-face discussion with that person is necessary. Thus, effective disseminators of external information do more than just redirect an email to a relevant colleague. They have to possess the technical competence to discuss with the recipient how that information can be specifically exploited by the R\&D group:

It depends on the type of tool or process that they would send to me. If it was something straightforward ... something I was familiar with, well then I could probably implement it myself. But l'd often have a discussion with the person because l'd be curious as to why they thought that information was relevant to met. Obviously it was something they were passionate enough about to send me an e-mail, so I would definitely review whatever it was they sent me ... and if it was something that I thought was worthwhile, l'd definitely try to use it. I might try to build a prototype, or I might get another project member involved.

\section{DISCUSSION}

The motivation for this study is to examine how the online and offline components of the R\&D social network combine to facilitate the diffusion of valuable information. We now discuss the theoretical and practical implications of our findings as well as the limitations and areas for further research.

\section{Theoretical implications}

We firstly consider the theoretical implications of our SNA findings followed by a discussion of the qualitative evidence. The SNA findings from this study of a telecommunications firm confirm those of our earlier pilot study with a medical devices firm (Whelan et al., 2010). The technological gatekeeper, as defined in Allen's seminal research (Allen \& Cohen, 1969; Allen, $1971 ; 1977)$, did not exist to any great extent in the R\&D social network. Instead, we find from the network analysis that the gatekeeper role has undergone a division of labour. A small 
number of R\&D professionals identify and gather potentially valuable information (such as emerging technologies, trends and ideas) from the world outside. By and large, these individuals are different to those who translate and disseminate that information throughout the internal R\&D network.

These SNA findings are consistent with a number of studies from the field of sociology, which also report that the diffusion of novel information throughout social networks requires a combination of external and internal communication 'stars' (Weimann, 1982; Harada, 2003). However, contemporary social networks can be fully or partially digitised and we extend these studies by using qualitative methods to examine the interplay between the online and offline components of social networks. Our evidence shows that while technology can certainly amplify networking practices, it can not replace the human ingenuity needed to translate and disseminate information into a form that ensures its consumption by others. Our thoughts in this regard are consistent with those of Lanzara (1983), who explored the behaviour of organisations in response to extreme events. In the aftermath of a disaster such as an earthquake, Lanzara provides illustrative accounts of the emergence of new organisational forms and how certain individuals evolve into positions such as 'the coffeemaker'. In a similar vein, our interview evidence strongly suggests that the emergence of Web-based communication technologies, and the resulting problem of information overload, is largely responsible for the evolution and fragmentation of the gatekeeper into specialist roles.

Additionally, IS scholars have previously suggested that communication platforms such as online forums, wiki and blogs would diminish the need for technological gatekeepers in R\&D networks (Teigland \& Wasko, 2003; Assimakopoulos \& Yan, 2006). We find partial support for these pronouncements. While the gatekeeper as a single individual has been mitigated, the gatekeeper role of acquiring, translating and disseminating external information remains as important as ever. Underpinned by our findings from this case study, and building upon our earlier study with a medical device firm (Whelan et al. 2010), we now offer an updated conceptual framework of the technological gatekeeper in figure 3.

The framework uses the analogy of a double-sided funnel to explain the gatekeeping diffusion process in the modern R\&D network. Allen's gatekeeper existed in a time when external information sources were scarce and difficult to access. In relative terms, their network of external contacts was small and limited to those they knew personally. Today, the opposite is true. Social networks are ever faster and larger as workers use a variety of online tools to connect with information sources from around the globe. As reflected in the framework, the locus of external information acquisition has shifted from personal networks to online networks. This shift has consequences. Where once the problem was information scarcity, now the problem is one of information overload. As a result, distilling the potentially valuable information into the R\&D funnel has become a complex and time-consuming process, necessitating the attentions of a specialist, i.e. the external communication star. The external stars are skilled in scouting for external information, but the translation and dissemination of that information requires a different skill set. This is the domain of a different specialist - the internal communication star. Before approaching the internal star to discuss how the information they have acquired can be exploited, the external star will firstly verify that information to be accurate and 


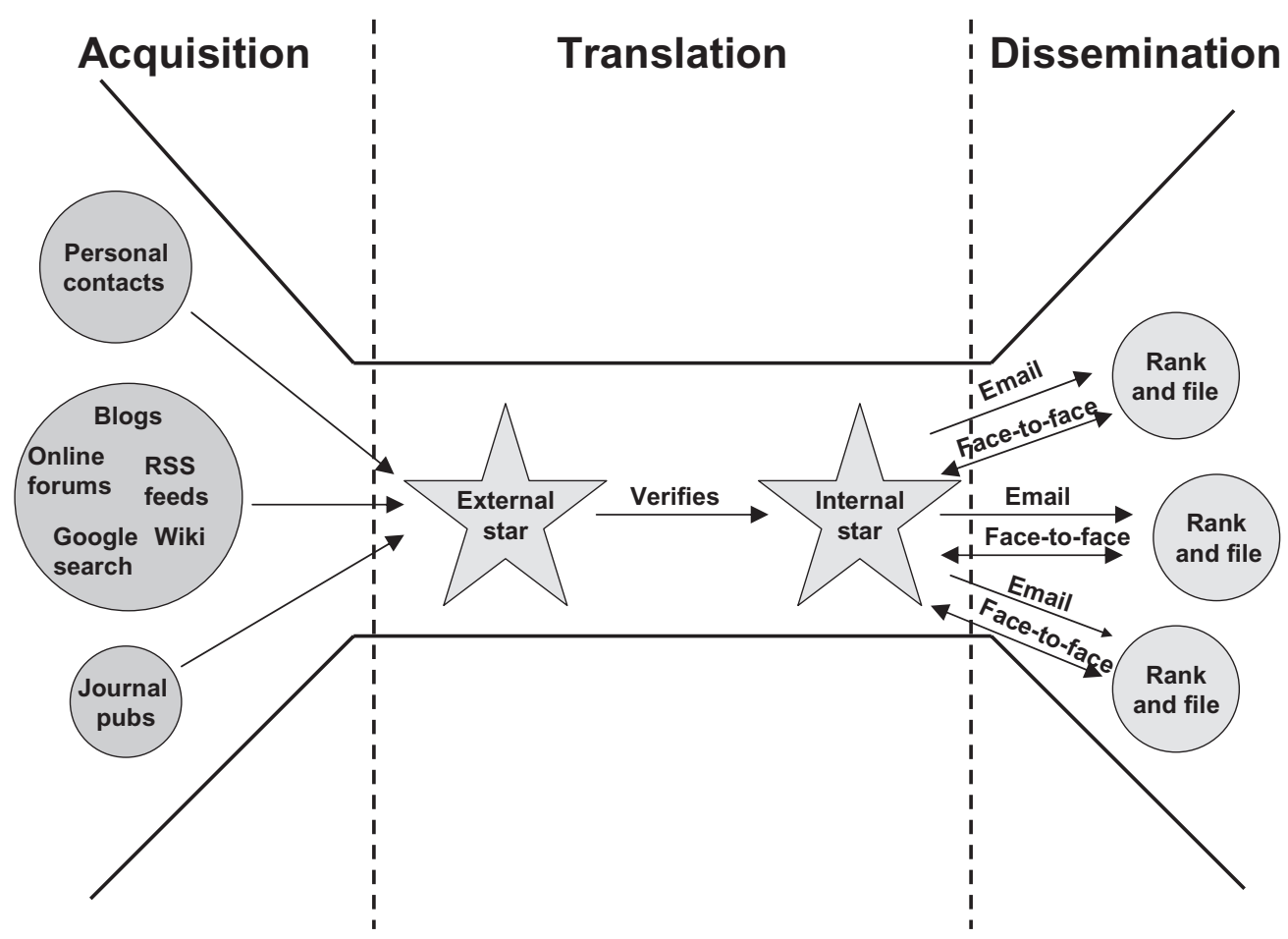

Figure 3. The updated gatekeeper conceptual framework.

reliable. The great advantage of the internet is that anyone can publish their thoughts on it, but how can the users of that information be sure of its accuracy and reliability? As noted by prominent IS scholar Eric Brynjolfsson, 'While it's true that everyone can weigh in on just about every topic on the internet today, that doesn't mean everyone always should . . you don't have to be a climate change expert to edit the Wikipedia entry on global warming . . ' (Brynjolfsson \& McAfee, 2007). As much of the novel information is sourced from the internet, the verification of information has now become an integral step in the information translation process.

Due to their extensive comprehension of the internal R\&D operations, the internal stars are well placed to understand how the information passed to them can potentially be exploited by the firm. The internal star will usually identify a small number of 'rank-and-file' colleagues who are best placed to make use of that information and will translate the external information into a form that is understandable and relevant to them. The first step in disseminating this information involves the internal star sending an email alerting the recipient to the novel information. The email will include a three- to four-sentence translation that explains why the internal star believes the information contained is relevant to the recipient. This three- to four-sentence translation is necessary because similar to the other end of the funnel, information overload is also a significant problem internally. The interviewees in this study revealed 
that they were swamped with the number of emails they receive daily. Thus, they tend to read just the opening lines of an email through the preview mode and will then decide from that whether to read further or delete. If the information is of interest to the recipient, they then return to the internal star and have a face-to-face discussion about how that information can be exploited.

\section{Practical implications}

The spread of technological information throughout the internal social network is critical to the innovation process in product development settings. The primary benefit of this study to practitioners is the identification of the role and skills exhibited by the small number of individuals who are disproportionately responsible for diffusing valuable information throughout the R\&D social network. Due to the digitisation of social networks, these roles and skills have altered significantly since the original gatekeeper studies were conducted over 30 years ago. Our study updates the gatekeeper concept and provides R\&D organisations with the information required to identify these competencies in the individuals within their talent pools and to deploy these individuals in positions that will maximise their contribution to the firm's innovative capabilities.

As described in Table 3 earlier, those who possess a genuine interest in keeping up-todate with industry developments, who maintain a narrow and deep expertise in a particular field (as evidenced by a PhD qualification) and who possess strong analytical skills are best suited to the external star position. This is primarily due to the vast array of information sources made easily accessible with the prevalence of internet technologies. It is only with a deep knowledge of a specific field that a person can distil the valuable information from the rest. To maximise their contribution to the information flow network, external stars should be freed from any mundane administrative duties and be allocated the time they need to scan the external environment for emerging technologies and trends. In terms of resources, all they need is a personal computer with an internet connection. However, it would be more beneficial if external stars are given priority for external networking events such as conferences or tradeshows.

It could be argued that through Darwinistic procedures, the traditional technological gatekeeper has adapted to the information revolution brought about by internet technologies and evolved into a specialist internal communication star. Internal stars have a natural flair for getting to know others. Rather than possessing a deep knowledge of a specialist field, these individuals are good all-rounders. If management fails to recognise the valuable role performed by these individuals, there is a danger that their information dissemination efforts could be stifled. Internal stars need the opportunity to network. Involving these individuals in multiple projects throughout the firm will enable them to build their network more rapidly, allowing them to become more effective disseminators of information. Additionally, specific attention should be given to establishing connections between the external stars and the internal stars of a particular grouping. This study finds that it is primarily through these particular connections that valuable external information becomes integrated into the firm. 


\section{CONCLUSION}

In this study, we addressed the research question: how has the digitisation of the R\&D social network impacted the role of the technological gatekeeper? In sum, we find that online and offline social networks intertwine to diffuse external information into and around the R\&D unit. As a consequence of the increased digitisation of the R\&D social network, very few of the R\&D professionals studied fitted the classic definition of a technological gatekeeper. Instead, the gatekeeper has fragmented into specialist roles. The multitude of potentially valuable information easily accessible online necessitates that the acquisition of external information is performed by a small number of uniquely skilled external communication specialists. Acquiring external information has become a complex and time-consuming process that limits the external star's ability to translate and disseminate information. This role is performed by the specialist internal communication stars. The internal star uses a combination of email and face-to-face discussions to disseminate potentially useful information throughout the R\&D network.

This study is subject to a number of limitations that future studies should aim to address. Firstly, a strength of the SNA evidence was the decision to only include reciprocated interactions for measures of internal communication. This ensured that respondents who mistakenly or purposefully exaggerated their level of internal communications did not distort the analysis. A limitation of the study was that a similar check mechanism could not be used to validate respondents' level of external communications. Secondly, the evidence underpinning this framework is based largely on one case study of a telecommunications firm. This study focused upon development-focused software engineers who were, for the most part, of Irish nationality. As explained by Yin (1994), this allows us to make analytical generalisations to previously developed theory, but it would be a mistake to attempt to make statistical generalisations to a wider population. For the purposes of statistical generalisability and to validate the framework, future research studies should examine multiple R\&D groups in differing industries and cultural settings.

\section{REFERENCES}

Agarwal, R., Gupta, A.K. \& Kraut, R. (2008) The interplay between digital and social networks. Information Systems Research, 19, 243-252.

Aldrich, H.E. \& Herker, D. (1997) Boundary spanning roles and organization structure. Academy of Management Review, 2, 217-230.

Allen, T.J. (1971) Communication networks in R\&D laboratories. R\&D Management, 1, 14-21.

Allen, T.J. (1977) Managing the Flow of Technology. MIT Press, Cambridge, MA, USA.

Allen, T.J. \& Cohen, S.I. (1969) Information flow in research and development laboratories. Administrative Science Quarterly, 14, 12-19.
Allen, T.J., Tushman, M.L. \& Lee, D.M.S. (1979) Technology transfer as a function of position in the spectrum from research through development to technical services. Academy of Management Journal, 22, 694708.

Allen, J., James, A.D. \& Gamlen, P. (2007) Formal versus informal knowledge networks in R\&D: a case study using social network analysis. R\&D Management, 37, 179-196.

Aral, S., Brynjolfsson, E. \& Van Alstyne, M. (2007) Productivity effects of information diffusion in email networks. 28th Annual International Conference on Information Systems, Montreal, CA, USA. 
Assimakopoulos, D. \& Yan, J. (2006) Sources of knowledge acquisition for Chinese software engineers. $R \& D$ Management, 36, 97-106.

Bampo, M., Ewing, M.T., Dineli, M.R., Stewart, D. \& Wallace, M. (2008) The effects of social structure of digital networks on viral marketing. Information Systems Research, 19, 273-290.

Barabasi, A.L. (2003) Linked. Plume, New York, USA.

Benbasat, I., Goldstein, D.K. \& Mead, M. (1987) The case research strategy in studies of information systems. MIS Quarterly, 11, 369-386.

Binney, D. (2002) The knowledge management spectrum: the human factor. In: Knowledge Management in the Sociotechnical World. The Graffiti Continues, Coakes, E., Willis, D. \& Clarke, S. (eds), pp. 17-29. Springer, London, UK.

Birley, S. (1985) The role of networking in the entrepreneurial process. Journal of Business Venturing, 1, 107117.

Borgatti, S.P., Everett, M.G. \& Freeman, M.C. (2002) UCINET 6.0 Version. Analytic Technologies, Harvard, MA, USA.

Brown, M. (2007) Social Computing Upends Past Knowledge Management Archetypes. Forrester, Cambridge, MA, USA.

Brown, J.S. \& Duguid, P. (2000) The Social Life of Information. Harvard Business School Press, Boston, MA, USA.

Brynjolfsson, E. \& McAfee, A. (2007) The future of the Web: beyond enterprise 2.0", MIT Sloan Management Review, 48, 49-55.

Burt, R.S. (1992) Structural Holes: The Social Structure of Competition. Harvard Business Press, Cambridge, MA, USA.

Chen, M.H. \& Wang, M.C. (2008) Social networks and new venture's innovative capability: the role of trust within entrepreneurial teams. R\&D Management, 38, 253-264.

Chesbrough, H.M. (2003) Open Innovation. Harvard Business School Press, Boston, MA, USA.

Christakis, N.A. \& Fowler, J.H. (2009) Connected. Little Brown and Company, London, UK.

ClO.com (2008) Increased investment, more implementations expected for enterprise Web 2.0 technologies. Retrieved 17 September 2008 [WWW document]. URL http://www.cio.com/article/177959/Increase/?source= artrel_top

Coakes, E. (2002) Knowledge management: a sociotechnical perspective. In: Knowledge Management in the Sociotechnical World. The Graffiti Continues, Coakes, E., Willis, D. \& Clarke, S. (eds), pp. 4-14. Springer, London, UK.
Coakes, E., Sugden, G., Russell, S., Camilleri, J.P. \& Bradburn, A. (2002) Managing tacit knowledge in knowledge-intensive firms: is there a role for technology? In: Knowledge Management in the Sociotechnical World. The Graffiti Continues, Coakes, E., Willis, D. \& Clarke, S. (eds), pp. 185-197. Springer, London, UK.

Cohen, W. \& Levinthal, D. (1990) Absorptive capacity: a new perspective on learning and innovation. Administrative Science Quarterly, 35, 128-152.

Coleman, J., Katz, E. \& Mensel, H. (1966) Medical Innovation; A Diffusion Study. Bobbs-Merrill Co., Indianapolis, IN, USA.

Cross, R. \& Parker, A. (2004) The Hidden Power of Social Networks. Harvard Business School Publishing, Boston, MA, USA.

Cross, R. \& Prusak, L. (2002) The people that make organizations stop or go. Harvard Business Review, 80, 104112.

Cross, R., Borgatti, S.P. \& Parker, A. (2002) Making invisible work visible: using social network analysis to support strategic collaboration. California Management Review, 44, 25-46.

Davenport, T. (2005) Thinking for a Living. Harvard Business School Press, Boston, MA, USA.

Davenport, T. \& Prusak, L. (2000) Working Knowledge; How Organizations Manage What They Know. Harvard Business School Press, Boston, MA, USA.

Doak, S. \& Assimakopoulos, D. (2007) How forensic scientists learn to investigate cases in practice. $R \& D$ Management, 37, 113-122.

Eisenhardt, K.M. \& Graebner, M.E. (2007) Theory building from cases: opportunities and challenges. Academy of Management Journal, 50, 25-32.

Ganley, D. \& Lampe, C. (2009) The ties that bind: social network principles in online communities. Decision Support Systems, 47, 266-274.

Gibson, D.R. (2005) Taking turns and talking ties: networks and conversational interaction. American Journal of Sociology, 6, 1561-1597.

Granovetter, M. (1973) The strength of weak ties. American Journal of Sociology, 78, 1360-1380.

Harada, T. (2003) Three steps in knowledge communication: the emergence of knowledge transformers. Research Policy, 32, 1737-1751.

Hinz, O. \& Spann, M. (2008) The impact of information diffusion on bidding behaviour in secret reserve price auctions. Information Systems Research, 19, 351-368.

Kane, G.C. \& Alavi, M. (2008) Casting the net: a multimodal perspective on user-system interactions. Information Systems Research, 19, 253-272. 
Katz, E. \& Lazarsfeld, P.F. (1955) Personal Influence: The Part Played by People in the Flow of Mass Communications. The Free Press, Glencoe, IL, USA.

Katz, R. \& Tushman, M. (1981) An investigation into the managerial roles and career paths of gatekeepers and project supervisors in a major R\&D facility. $R \& D$ Management, 11, 103-110.

Katz, R. \& Tushman, M. (1983) A longitudinal study of the effects of boundary spanning supervision on turnover and promotion in research and development. Academy of Management Journal, 26, 427-456.

Kings, N.J., Davies, J., Verrill, D., Aral, S., Brynjolfsson, E. \& Van Alstyne, M. (2008) Social networks, social computing and knowledge management. In: ICT Futures, Warren, P., Davies, J. \& Brown, D. (eds), pp. 17-26. John Wiley \& Sons, London, UK.

Kudaravailli, S. \& Faraj, S. (2008) The structure of collaboration in electronic networks. Journal of the Association of Information Systems, 9, 706-736.

Lanzara, G.F. (1983) Ephemeral organizations in extreme environments: emergence, strategy, extinction. Journal of Management Studies, 20, 71-95.

Lazarsfeld, P.F., Berelson, B. \& Gaudet, H. (1948) The People's Choice. Columbia University Press, New York, USA.

Leonard-Barton, D. (1992) Core capabilities and core rigidities: a paradox in managing new product development. Strategic Management Journal, 17, 93-108.

Lionel, R., Alan, D. \& Ahuja, M. (2008) Social capital and knowledge integration in digitally enabled teams. Information Systems Research, 19, 314334.

Macdonald, S. \& Williams, C. (1993) Beyond the boundary: an information perspective on the role of the gatekeeper in the organization. Journal of Product Innovation Management, 10, 417-427.

Macdonald, S. \& Williams, C. (1994) The survival of the gatekeeper. Research Policy, 23, 123-132.

March, J.G. \& Simon, H. (1958) Organizations. Wiley, New York, USA.

McKinsey Consulting (2007) How businesses are using Web 2.0: a McKinsey global survey. Retrieved 30 March 2007 [WWW document]. URL http://www.mckinsey quarterly.com/article_abstract_visitor.aspx?ar=1913\& $12=13 \& \mid 3=11 \&$ srid $=17 \& \mathrm{gp}=0$

Miles, M.B. \& Huberman, A. (1984) Qualitative Data Analysis. Sage, London, UK.

Moreno, J.L. (1937) Sociometry in relation to other social sciences. Sociometry, 1, 206-219.
Myers, M.D. \& Newman, M. (2007) The qualitative interview in IS research: examining the craft. Information and Organization, 17, 2-26.

Nahapiet, J. \& Ghoshal, S. (1998) Social capital, intellectual capital, and the organizational advantage. Academy of Management Review, 23, 242-266.

Newell, S. \& Swan, J. (2000) Trust and inter-organizational networking. Human Relations, 53, 1287-1328.

Newell, S., Robertson, M., Scarbrough, H. \& Swan, J. (2009) Managing Knowledge Work \& Innovation. Palgrave, London, UK.

Nooteboom, B. (2004) Inter-Firm Collaboration, Learning and Networks. Routledge, London, UK.

OECD. (2006) Review of higher education in Ireland. [WWW document] http://www.oecd.org/dataoecd/30/46/ 37844047.pdf

Parameswaran, M. \& Whinston, A.B. (2007) Research issues in social computing. Journal of the Association for Information Systems, 8, 336-350.

Parise, S. (2009) Social media networks: what do they mean for knowledge management. Journal of Information Technology Case and Application Research, 11, 1-11.

Roberts, J., Hann, I.H. \& Slaughter, S. (2006) Understanding the motivations, participation, and performance of open source software developers: a longitudinal study of apache projects. Management Science, 52, 984999.

Rogers, E.M. (1995) Diffusion of Innovations. The Free Press, New York, USA.

Salganik, M., Dodds, P.S. \& Watts, D.J. (2006) Experimental study of inequality and unpredictability in an artificial cultural market. Science, 10, 854-856.

Schenkel, A. \& Teigland, R. (2008) Improved organizational performance through communities of practice. Journal of Knowledge Management, 12, 106-118.

Shah, S. (2006) Motivations, governance, and the viability of hybrid forms in open source software development. Management Science, 52, 1000-1014.

Silva, L., Goel, L. \& Mousavidin, E. (2008) Exploring the dynamics of blog communities: the case of MetaFilter. Information Systems Journal, 19, 55-81.

Su, N., Mark, M.G. \& Sutton, S.A. (2007) Workplace connectors as facilitators for work. Proceedings of the 3rd International Conference on Communities and Technologies, East Lansing, MI, USA, 131-150.

Swan, J., Newell, S., Scarbrough, J. \& Hislop, D. (1999) Knowledge management and innovation: networks and networking. Journal of Knowledge Management, 3, 262275. 
Teigland, R. \& Wasko, M. (2003) Integrating knowledge through information trading: examining the relationship between boundary spanning communication and individual performance. Decision Sciences, 34, 261-287.

Tushman, M. (1977) Special boundary roles in the innovation process. Administrative Science Quarterly, 22, 587605.

Tushman, M. \& Katz, R. (1980) External communication and project performance: an investigation into the role of gatekeepers. Management Science, 26, 1071-1085.

Tushman, M. \& Scanlan, T. (1981) Boundary spanning individuals: their role in information transfer and their antecedents. Academy of Management Journal, 24, 289-305.

USA Today (2010) Social media play part in recovery efforts. USA Today, Monday, 1 February 2010, p. 5A.

Wasko, M. \& Faraj, S. (2005) Why should I share? Examining social capital and knowledge contribution in electronic networks of practice. MIS Quarterly, 29, 35-57.

Wasko, M., Faraj, S.A. \& Teigland, R. (2004) Collective action and knowledge contribution in electronic networks of practice. Journal of the Association for Information Systems, 5, 493-513.

Wasserman, S. \& Faust, K. (1994) Social Network Analysis: Methods and Application. Cambridge University Press, Cambridge, UK.

Watts, D.J. (2004) Six Degrees: The Science of a Connected Age. Vintage, London, UK.

Weimann, G. (1982) On the importance of marginality: one more step into the two-step flow of communication. American Sociological Review, 47, 764-773.

Wenger, E., McDermott, R. \& Snyder, W.W. (2002) Cultivating Communities of Practice. Harvard Business School Press, Boston, MA, USA.

Whelan, E., Teigland, R., Donnellan, B. \& Golden, W. (2010) How internet technologies impact information flows in R\&D: revisiting the technological gatekeeper. $R \& D$ Management, 40, 400-413.

Yin, R.K. (1994) Case Study Research; Design and Methods. Sage, London, UK.

\section{Biographies}

Eoin Whelan is a Lecturer in Information Management, Kemmy Business School, University of Limerick, Ireland. Previously he was on the faculty of the Cairnes School of Business and Economics in NUI Galway. He received his PhD from NUl Galway in 2009. His research interests focus upon information networks, with a particular emphasis on open and networked innovation and the role of information and communication technologies within these paradigms. His works have appeared in a variety of journals including MIT Sloan Management Review, Journal of Information Technology, R\&D Management, and Journal of Knowledge Management. Prior to becoming an academic, Eoin held a variety of business analyst positions in Ireland, New Zealand, and the US.

Brian Donnellan holds the chair of Information Systems Innovation at the National University of Ireland Maynooth (www.nuim.ie) and is Co-Director of the Innovation Value Institute (www.ivi.ie). Prior to joining NUI Maynooth, Prof. Donnellan was a faculty member in the National University of Ireland, Galway. He has spent 20 years working in the ICT industry where he was responsible for the provision of IS to support Product Development. $\mathrm{He}$ is an expert evaluator for the European Commission and has been guest and associate editor of several leading IS journals including Journal of IT, Journal of Strategic Information Systems and MIS Quarterly.

Willie Golden is Professor and Dean of the College of Business, Public Policy and Law at NUI Galway Ireland. Previously he was the Director of the Centre for Innovation and Structural Change at NUI, Galway. He completed his doctorate on Electronic Commerce at the University of Warwick, England. He has co-authored a book, contributed 10 chapters to other texts and published 16 journal papers in the areas of Electronic Commerce and Information Systems.in among others, Omega, The International Journal of Management Science, International Journal of Electronic Commerce, Journal of End User Computing and Journal of Decision Systems. 
APPENDIX 1: COPY OF THE SNA QUESTIONNAIRE

Copy of SNA Questionnaire

Page 1 of 2

Copy of SNA Questionnaire

Exit this survey $>>$

\section{Introduction}

Please answer all 4 questions. The questionnaire will only take $2-3$ minutes to complete.

\section{*1. Your name?}

2. Please identify which work colleagues you discuss technical issues with at least once a week? [Please check all that apply]

\begin{tabular}{|c|c|c|}
\hline$\Gamma$ AA & $Г \mathrm{EE}$ & $-\mathrm{II}$ \\
\hline । BB & I FF & נ נ \\
\hline$L^{c c}$ & $L^{G G}$ & ${ }_{-}^{\mathrm{KK}}$ \\
\hline$\sqsubset \mathrm{DD}$ & $Г \mathrm{HH}$ & $-\mathrm{LL}$ \\
\hline
\end{tabular}

3. How often do you use the following information sources in your every day work?

\begin{tabular}{|c|c|c|c|c|c|c|c|}
\hline & $\begin{array}{l}\text { Several } \\
\text { times a } \\
\text { day }\end{array}$ & $\begin{array}{c}\text { Once a } \\
\text { day }\end{array}$ & $\begin{array}{l}\text { Once } \\
\text { every two } \\
\text { days }\end{array}$ & $\begin{array}{c}\text { Once a } \\
\text { week }\end{array}$ & $\begin{array}{l}\text { Once } \\
\text { every two } \\
\text { weeks }\end{array}$ & $\begin{array}{l}\text { Once a } \\
\text { month }\end{array}$ & $\begin{array}{l}\text { More } \\
\text { seldom }\end{array}$ \\
\hline \{Firm Name\} & & & & & & & \\
\hline $\begin{array}{l}\text { colleagues in } \\
\text { other departments }\end{array}$ & 0 & () & ( ) & $\approx$ & () & ( ) & $\because$ \\
\hline $\begin{array}{l}\text { Contacts outside } \\
\text { \{Firm Name\} that } \\
\text { you know }\end{array}$ & & & & & & & \\
\hline $\begin{array}{l}\text { personally } \\
\text { (including face-to- } \\
\text { face, phone, and } \\
\text { email contacts) }\end{array}$ & 0 & $\mathrm{O}$ & $\mathrm{O}$ & c & 0 & $\mathrm{O}$ & c \\
\hline $\begin{array}{l}\text { Academic } \\
\text { publications }\end{array}$ & 0 & 0 & 0 & $\mathrm{C}$ & $\sigma$ & 0 & 2 \\
\hline $\begin{array}{l}\text { Internet (other } \\
\text { than accessing }\end{array}$ & & & & & & & \\
\hline $\begin{array}{l}\text { journal papers i.e. } \\
\text { websites, } \\
\text { discussion forums, } \\
\text { wikis, blogs) }\end{array}$ & 0 & 0 & $\mathrm{O}$ & 8 & $\mathrm{O}$ & 0 & 2 \\
\hline
\end{tabular}

4. Please identify sources outside of the R\&D Group who are important in terms of providing you with information to do your work? [e.g. a specific website or contacts in another organisation]

1.

2.

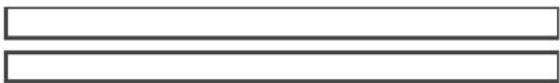

http://www.surveymonkey.com/s.aspx?sm=ydRzXOjqt2MDikYm_2bycaeQ_3d_3d 